\title{
PENGARUH MOTIVASI DAN DIKLAT TERHADAP KINERJA KARYAWAN SWASTA (STUDI KASUS : PT. HASRAT TATA JAYA PEKANBARU)
}

\author{
Muhammad Ali Aqsa \\ Sekolah Tinggi Ilmu Ekonomi Indragiri Riau \\ E-mail: muh.ali.aqsa@gmail.com
}

\begin{abstract}
This study aims to determine the impact of motivation and education and training on the performance of private employees, in which this research was conducted at PT. Hasrat Tata Jaya Pekanbaru. The number of samples in this study was determined based on Slovin formula, so that a sample of 72 people was obtained, while the approach used in sampling was through simple random sampling. While the data analysis in this study uses quantitative methods with multiple linear regression. Based on the results of research on the motivation variable, the results obtained that the value of $t$ count is greater than t table (2.652> 1.994) with a significance level of 0.010 smaller than 0.05. Then $H_{1}$ is accepted. Based on the results of the t test above it can be concluded that motivation has a positive and significant effect on the performance of employees at PT. Hasrat Tata Jaya Pekanbaru. While the results of testing on education and training variables, the results obtained that the value of t count is greater than table (2,084> 1,994) with a significance level of 0.041 smaller than 0.05. Then $\mathrm{H}_{2}$ is accepted, Based on the results of the t test above it can be concluded that education and training has a positive and significant effect on the performance of employees at PT. Hasrat Tata Jaya Pekanbaru. In a simultaneous test ( $F$ test), obtained $f$ count greater than $f$ table that is equal to 86,600> 3.13 with a significance level of 0,000 smaller than 0.05, this means that $H_{3}$ is accepted. Which means that simultaneously the motivation and education variables and training have a positive and significant effect on employee performance variables. So it can be concluded that motivation and education and training together (simultaneous) have a positive and significant effect on the performance of private employees at PT. Hasrat Tata Jaya Pekanbaru. The large impact caused by the two variables is $71.50 \%$, this explains that motivation and education and training have an effect of $71.50 \%$ on the performance of employees at PT. The Desire of Tata Jaya Pekanbaru, while the rest was not assessed in this study
\end{abstract}

Keywords: Motivation, Education and Training, Employee Performance

\section{A. PENDAHULUAN}

Sumber daya manusia merupakan salah faktor penentu dalam proses pembangunan dan pengembangan yang dinamis sehingga dibutuhkan peranan yang lebih besar. Keberhasilan suatu organisasi dalam mencapai tujuan ditentukan oleh kualitas dan kemampuan sumber daya manusia. Sumber daya manusia pada perusahaan perlu dikelola secara profesional agar terwujud suatu keseimbangan antara kebutuhan karyawan dengan tuntutan dan kemampuan organisasi perusahaan.

Salah satu pengelolaan sumber daya manusia dapat dilakukan melalui pemberian motivasi dan pendidikan pelatihan yang diberikan kepada karyawan. Pemberian motivasi dan pendidikan pelatihan dapat mendorong para karyawan bekerja lebih giat. Hal ini disebabkan karena karyawan akan berusaha mencapai prestasi kerja yang lebih tinggi. Melalui proses pemberian motivsi dan pendidikan pelatihan tersebut, kompetensi karyawan dapat ditingkatkan demi tercapainya standarisasi kompetensi yang dibutuhkan perusahaan untuk mencapai target yang telah direncanakan.

Pada umumnya setiap perusahaan memiliki tenaga kerja sebagai sumber daya manusia dalam mewujudkan visi misi perusahaan. PT. Hasrat Tata Jaya merupakan salah satu perusahaan kontraktor yang bergerak di bidang sipil. Berdasarkan data yang diperoleh dari PT. Hasrat Tata Jaya Pekanbaru mengenai jumlah karyawan, dapat diketahui bahwa setiap tahun selalu terjadi perubahan jumlah tenaga kerja setiap tahunnya. Jumlah tenaga kerja di PT. Hasrat Tata Jaya Pekanbaru dapat dilihat pada Tabel 1 berikut

\section{Tabel 1 Jumlah Karyawan PT. Hasrat}

\section{Tata Jaya}

\begin{tabular}{|c|c|c|}
\hline Tahun & Jumlah karyawan & Persentase (\%) \\
\hline 2013 & 288 & - \\
\hline 2014 & 288 & 0,00 \\
\hline 2015 & 224 & $-22,22$ \\
\hline 2016 & 256 & 14,29 \\
\hline 2017 & 263 & 2,73 \\
\hline
\end{tabular}


Sumber : PT. Hasrat Tata Jaya Pekanbaru, 2017

Berdasarkan Tabel 1 diatas, terjadi perubahan jumlah karyawan setiap tahunnya. Pada tahun 2015 terjadi penurunan jumlah karyawan sementara pada tahun berikutnya terjadi peningkatan jumlah karyawan. Perubahan jumlah tenaga kerja secara otomatis akan mempengaruhi kualitas dan kuantitas kinerja karyawan, karena semakin banyak tenaga kerja maka proyek yang dikerjakan akan lebih cepat selesai. Selain itu, perubahan jumlah tenaga kerja harus sejalan dengan peningkatan kualitas tenaga kerja. Sehingga Kinerja karyawan dapat meningkat dan dapat memberikan pelayanan yang baik kepada para konsumen.

Motivasi kerja menjadi pendorong seseorang melaksanakan suatu kegiatan guna mendapat hasil yang terbaik. Oleh karena itulah tidak heran jika karyawan yang mempunyai motivasi kerja yang tinggi biasanya mempunyai kinerja yang tinggi pula. Untuk itu motivasi kerja karyawan perlu ditingkatkan agar karyawan dapat menghasilkan kinerja yang terbaik. Selain itu juga jika ada seorangkaryawan dengan keadaan posisi yang kurang semangat terhadap pekerjaan maka perlu adanya sikap perhatian yang diberikan terhadap pemimpin untuk memotivasi karyawan tersebut.

PT. Hasrat Tata Jaya adalah perusahaan yang bergerak dalam bidang kontraktor. Kegiatan dalam perusahaan meliputi: pengembangan (yaitu: perumahan, perkantoran, gedung, dan irigasi), perencanaan, pengawasan, dan pelaksanaan pembangunan semenisasi jalan.Beberapa hasil pengamatan serta prasurvey yang telah dilakukan peneliti di PT. Hasrat Tata Jaya, yaitu dengan melakukan survey secara langsung menggunakan metode wawancara dengan pihak karyawan PT. Hasrat Tata Jaya sebagai sumber informasi. Adanya identifikasi berbagai indikatorindikatorpermasalahan yang dapat diperoleh dari wawancara sebagai berikut:

1. Kurangnya motivasi kerja karena tidak adanya target penjualan semen cair

Eko dan Bisnis (Riau Economics and Business Reviewe) Volume 10, Nomor 3, 27 September 2019 menggunakan molen yang harus dicapai oleh karyawan.

2. Sistem kerja yang tidak konstan karena menyesuaikan proyek yang dikerjakan (musiman).

3. Lokasi kerja yang berpindah-pindah menyesuaikan proyek yang sedang dikerjakan.

4. Penyelesaianproyek terkadang melebihi dari jadwalyangsudah ditentukan.

Berdasarkan latar belakang masalah dan fenomena yang terjadi, maka tujuan dari penelitian ini adalah bertujuan untuk mengetahui seberapa besar pengaruh yang ditimbulkan motivasi dan pendidikan dan pelatihan (diklat) terhadap kinerja pegawai swasta dalam hal ini studi kasus pada PT. Hasrat Tata Jaya Pekanbaru.

\section{TINJAUAN PUSTAKA}

Menurut pendapat yang
disampaikan oleh (Muhammad Ali Aqsa, 2018) manajemen sumber daya manusia adalah seni dan ilmu pengadaan, pengembangan dan pemanfaatan sumber daya manusia sehingga tujuan organisasi direalisasikan secara daya guna dan adanya kegairahan kerja dari semua tenaga kerja. Sedangan pendapat lain dikemukan oleh Menurut Andrew E. Sikula dalam (Mangkunegara, 2015), menyatakan bahwa manajemen sumber daya manusia adalah penarikan, penerimaan, pengembangan dan pemanfaatan sumber daya manusia dalam rangka pencapaian tujuan individu maupun organisasi.

Menurut Schuler, Dowling, Smart dan Huber dalam (Priyono, 2010) mengartikan manajemen sumber daya manusia sebagai pengakuan tentang pentingnya tenaga kerja organisasi sebagai sumber daya manusia yang sangat penting dalam memberi kontribusi bagitujuantujuan organisasi dan menggunakan beberapa fungsi dan kegiatan untuk memastikan bahwa SDM tersebut digunakan secara efektif dan adil bagi

P.ISSN: $1410-7988 \quad$ E.ISSN: $2614-123 X$ 
kepentingan individu, organisasi dan masyarakat.

Motivasi adalah pemberian daya penggerak yang menciptakan kegairahan kerja seseorang agar mau bekerja sama, bekerja efektif dan terintegrasi dengan segala daya upaya untuk mencapai kepuasan. Hasibuan, (2003). Motivasi dapat dikatakan sebagai suatu daya pendorong (drive force) yang menyebabkan orang berbuat sesuatu atau yang diperkuat karena takut akan sesuatu (Sedarmayanti, 2001).

Menurut Cardoso, (2003) motivasi sangat penting bagi karyawan agar mereka terus bersemangat dalam menjalankan tugasnya, pemberian motivasi mempunyai tujuan yaitu :
a. Mendorong gairah dan semangat kerja karyawan
b. Meningkatkan moral dan kepuasan kerja karyawan
c. Meningkatkan kinerja karyawan
d. Mempertahankan loyalitas dan kestabilan karyawan perusahaan
e. Menigkatkan kedisiplinan dan menurunkan tingkat absensi karyawan

Menurut Maslow yang dikutip oleh Hasibuan (2008), bahwa motivasi kerja karyawan dipengaruhi oleh kebutuhan fisik, kebutuhan akan keamanan dan keselamatan, kebutuhan sosial, kebutuhan akan penghargaan diri, dan kebutuhan perwujudan diri. Kemudian dari faktor kebutuhan tersebut diturunkan menjadi indikatorindikator untuk memenuhi tingkat motivasi kerja pada karyawan, yaitu :

1. Kebutuhan fisik, ditunjukkan dengan pemberian gaji yang layak kepada karyawan, pemberian bonus, uang makan, uang transport, fasilitas perumahan dan sebagainya.

2. Kebutuhan rasa aman dan keselamatan, ditunjukkan dengan fasilitas keamanan dan keselamatan kerja yang diantaranya seperti adanya jaminan sosial tenaga kerja, dana pensiun, tunjangan kesehatan, asuransi kecelakaan, dan perlengkapan keselamatan lainnya.

Eko dan Bisnis (Riau Economics and Business Reviewe) Volume 10, Nomor 3, 27 September 2019
3. Kebutuhan sosial, ditunjukkan dengan melakukan interaksi dengan orang lain yang diantaranya dengan menjalin hubungan kerja yang harmonis, kebutuhan untuk diterima dalam kelompok dan kebutuhan untuk mencintai dan dicintai.

4. Kebutuhan akan penghargaan, ditunjukkan dengan pengakuan kebutuhan akan penghargaan berdasarkan kemampuannya, yaitu kebutuhan untuk dihormati dan dihargai karyawan lain dan pimpinan terhadap prestasi kerjanya.

5. Kebutuhan perwujudan diri, ditunjukkan dengan sifat pekerjaan yang menarik dan menantang, dimana karyawan tersebut akan menyerahkan kecakapan, kemampuan, keterampilan dan potensinya. Dalam pemenuhan kebutuhan ini, dapat dilakukan oleh perusahaan dengan menyelenggarakan pendidikan dan pelatihan.

Notoadmodjo (2009) menyatakan dalam pengembangan sumber daya manusia, pendidikan dan pelatihan adalah upaya untuk mengembangkan sumber daya manusia, terutama untuk mengembangkan kemampuan intelektual dan kepribadian manusia. Pendidikan didalam suatu organisasi adalah suatu proses pengembangan kemampuan kearah yang diinginkan oleh organisasi yang bersangkutan. Sedangkan pelatihan adalah bagian dari proses pendidikan, yang tujuannya untuk meningkatkan kemampuan atau keterampilan khusus seseorang atau kelompok orang.

Hasibuan (2014) menyatakan bahwa "Pendidikan dan pelatihan adalah suatu proses untuk meningkatkan keahlian teoritis, konseptual dan moral pegawai". Dengan kata lain orang yang mendapatkan pendidikan dan pelatihan secara berencana cenderung lebih dapat bekerja secara terampil jika dibandingkan dengan pegawai yang tidak mengikuti pendidikan dan pelatihan. Oleh karena itu pendidikan dan pelatihan semakin penting karena tuntutan pekerjaan sebagai akibat dari perubahan

P.ISSN: 1410-7988 E.ISSN: 2614-123X 
situasi, kondisi kerja, dan kemajuan teknologi yang semakin hari semakin ketat persaingannya.

Menurut Kamsir (2016) pendidikan dan pelatihan memberikan banyak manfaat bagi karyawan yang mengikutiya. Adapun manfaat pendidikan dan pelatihan bagi karyawan sebagai berikut:

1. Perencanaan Karier kedepannya bagi karyawan agar lebih baik.

2. Karyawan akan memperoleh kompensasi yang lebih baik mengingat kemampuannya dalam mengerjakan pekerjaan meningkat.

3. Karyawan memiliki alat negosiasi yang lebih baik, karena sudah meiliki keahlian dan kemampuan tertentu.

4. Memiliki kepuasan tersendiri.

5. Diklat (pendidikan dan pelatihan) menjadi sarana liburan bagi karyawan.

Menurut Rivai (2004) menambahkan indikator dalam pendidikan dan pelatihan terdiri dari:

1. Materi yang dibutuhkan. Materi disusun dari estimasi kebutuhan, tujuan dan latihan. Kebutuhan dalam bentuk pengajaran keahlian khusus, menyajikan pengetahuan yang diperlukan.

2. Metode yang digunakan. Metode yang dipilih hendaknya sesuai dengan jenis pelatihan yang akan dilaksanakan.

3. Kemampuan instruktur pelatihan. Mencari sumber-sumber informasi lain yang mungkin berguna dalam mengidentifikasi kebutuhan pelatihan.

4. Sarana atau prinsip-prinsip pembelajaran Pedoman dimana proses pekerjaan akan lebih efektif.

5. Peserta. Sangat penting untuk memperhitungkan tipe pekerjaan dan jenis pekerjaan yang akan dilatih.

6. Evaluasi pelatihan. Hendaknya di evaluasi hasil yang di dapat dalam pelatihan, dan memperhitungkan tingkat reaksi, tingkat belajar, tingkah laku kerja, tingkat organisasi dan nilai akhir.

Menurut Mangkunegara (2007) faktor-faktor yang mempengaruhi pencapaian kinerja adalah faktor kemampuan (ability) dan faktor motivasi (Motivation).

Eko dan Bisnis (Riau Economics and Business Reviewe) Volume 10, Nomor 3, 27 September 2019
Kemampuan sendiri dapat dibentuk melalui Pendidikan dan Pelatihan seperti yang dikemukakan oleh Simanjuntak (2005) pelatihan merupakan bagian dari investasi SDM (human investment) untuk meningkatkan kemampuan dan keterampilan kerja, dan dengan demikian meningkatkan kinerja pegawai. Maka dari itu pendidikan dan pelatihan juga merupakan salah satu factor yang dapat mempengaruhi kinerja pegawai. Memotivasi merupakan salah satu faktor kunci bekerja dan mencapai kinerja yang tinggi. Gibson dalam Pasolong (2011) menyatakan kinerja seseorang ditentukan oleh kemampuan dan motivasinya untuk melaksanakan pekerjaan.Kegiatan memotivasi berkaitan dengan sejauhmana komitmen seseorang terhadap pekerjaannya dalam rangka mencapai tujuan organisasi. Pada dasarnya, yang membuat pegawai kehilangan motivasi adalah situasi dan kondisi pekerjaan itu sendiri.

Berdasarkan fenomena yang telah disajikan pada latarbelakang masalah diatas, maka hipotesis dalam penelitian ini adalah diduga Motivasi dan diklat secara parsial dan simultan berpengaruh signifikan dan positif terhadap kinerja pegawai pada PT. Hasrat Tata Jaya Pekanbaru.

\section{METODE}

Metode penelitian yang digunakan pada penelitian ini adalah dengan metode kuantitatif. Diaman uji kuantitatif merupakan metode kuantitatif dapat diartikan sebagai metode penelitian yang berlandaskan pada filsafat positivisme, digunakan untuk meneliti pada populasi atau sampel tertentu, pengumpulan data menggunakan instrumen penelitian, analisis data bersifat kuantitaif/statistik, dengan tujuan untuk menguji hipotesis yang ditetapakan (Sugiyono, 2015). Data primer pada penelitian ini diperoleh melalui penyebaran angket (kuesioner) kepada karyawan PT. Hasrta Tata Jaya Pekanbaru.

Populasi merupakan keseluruhan (universal) dari objek penelitian yang dapat berupa hewan, tubuhan, manusia, udara,

P.ISSN: 1410-7988 E.ISSN: 2614-123X 
gejala, nilai dan sebagainya. Sehingga objek ini dapat dijadikan sebagai sumber data penelitian (Bungin, 2008). Populasi pada penelitian ini adalah seluruh karyawan PT. Hasrat Tata Jaya Pekanbaru yang berjumlah 263 orang.

Sampel adalah suatu prosedur dimana hanya sebagian populasi yang diambil dan dipergunakan untuk menentukan sifat serta ciri yang dikehendaki dari suatu populasi (Syofian Siregar, 2016). Teknik pengambilan sampel yang digunakan dalam penelitian ini adalah pemilihan sampel acak sederhana. Menurut Syofian Siregar (2016:), sampel acak sederhana (Simple Random Sampling) adalah teknik pengambilan sampel yang memberikan kesempatan yang sama kepada setiap anggota yang ada dalam suatu populasi untuk dijadikan sampel. Untuk mendapatkan jumlah sampel (n) yang akan diteliti dalam populasi, akan digunakan rumus Slovin, berdasarkan perhitungan dengan rumus Slovin diperoleh sampel sebanyak 72 responden.

Dalam metode analisis data ini, peneliti menggunakan regresi linier sederhana dengan model sebagai berikut :

$\mathrm{Y}=\mathrm{a}+\mathrm{b} 1 \mathrm{X} 1+\mathrm{b} 2 \mathrm{X} 2+\mathrm{e}$

Keterangan :

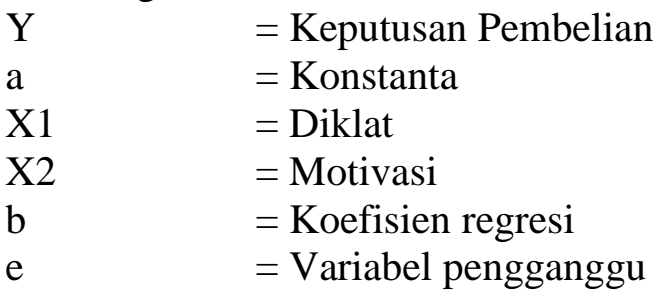

\section{HASIL}

Berdasarkan hasil uji validitas yang dilakukan, seluruh item penyataan dalam penelitian ini dinyatakan valid dimana $r$ hitung lebih besar dari $r$ tabel. Pada uji reliabilitas, variabel dalam penelitian ini dinyatakan reliabel atau layak, dimana hasil pengujian melalui SPSS 25 diperoleh hasil cronbach's alpha lebih besar dari 0.6. Dan berdasarkan uji normalitas, dapat dinyatakan bahwa sebaran data yang mendekati garis diagonal maka sebaran data memenuhi asumsi normalitas. Sehingga dapat disimpulkan bahwa data jawaban responden sudah berdistribusi normal.

Hasil pengolahan regresi linier berganda dengan menggunakan SPSS 25 adalah sebagai berikut:

\section{Tabel 2 : Coefisien Regresi}

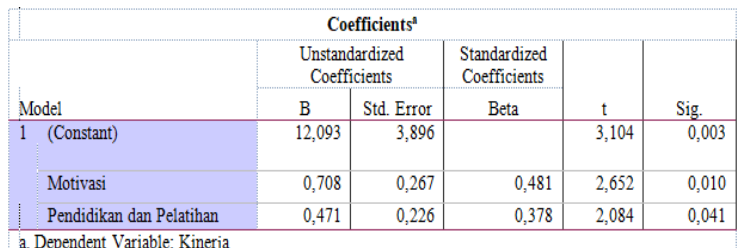

Sumber : Hasil Olahan Data SPSS 25, 2018

Untuk mengetahui variabel yang berpengaruh signifikan secara individu (parsial) dilakukan pengujian koefisien regresi dengan menggunakan statistik Uji t. Penentuan hasil pengujian (penerimaan/ penolakan H0) dapat dilakukan dengan membandingkan t-hitung dengan t-tabel atau juga dapat dilihat dari nilai signifikansinya. Adapun nilai t tabel dari penelitian ini adalah dengan tingkat signifikansi $5 \%$, adalahnilai df sebesar (n -k), dimana $\mathrm{n}=$ jumlah sampel dan $\mathrm{k}=$ jumlah variabel, maka hasilnya $(72-3=$ 69). Dalam t tabel angka 69 dengan tingkat signifikansi 0.05 adalah sebesar 1,994. Berikut hasil tabel uji $\mathrm{t}$ berdasarkan pengolahan data SPSS 25.

\section{Pengaruh Motivasi Secara Parsial Terhadap Kinerja Karyawan Pada PT. Hasrat Tata Jaya Pekanbaru.}

Berdasarkan pada tabel 2 diatas, dapat dilihat bahwa nilai $\mathrm{t}$ hitung lebih besar dari $t$ tabel $(2,652>1,994)$ dengan tingkat signifikansi 0,010 lebih kecil dari 0,05 . Maka $\mathrm{H}_{1}$ diterima, yang mana berarti bahwa variabel motivasi berpengaruh positif dan signifikan terhadap variabel kinerja karyawan. Berdasakan hasil uji $\mathrm{t}$ diatas dapat disimpulkan bahwa motivasi berpengaruh positif dan signifikan terhadap kinerja karyawan pada PT. Hasrat Tata Jaya Pekanbaru.

Penelitian ini sejalan dengan penelitian yang dilakukan oleh (Rahsel, 2016) dari perguruan tinggi Sekolah Tinggi Manajemen Informatika dan Komputer 
Pringsewu Lampung dimana hasil penelitian menyatakan bahwa motivasi kerja berpengaruh positif terhadap Kinerja Pegawai Administrasi Pusat Universitas Padjadjaran Bandung (Studi Pada Bagian Administrasi Umum Unpad).

\section{Pengaruh Pendidikan dan Pelatiah} (Diklat) Secara Parsial Terhadap Kinerja Karyawan Pada PT. Hasrat Tata Jaya Pekanbaru.

Berdasarkan pada tabel 2 diatas, dapat dilihat bahwa nilai t hitung lebih besar dari t tabel $(2,084>1,994)$ dengan tingkat signifikansi 0,041 lebih kecil dari 0,05. Maka $\mathrm{H}_{2}$ diterima, yang mana berarti bahwa variabel Pendidikan dan Pelatiah berpengaruh positif dan signifikan terhadap variabel kinerja karyawan. Berdasakan hasil uji $\mathrm{t}$ diatas dapat disimpulkan bahwa pendidikan dan pelatihan (diklat) berpengaruh positif dan signifikan terhadap kinerja karyawan pada PT. Hasrat Tata Jaya Pekanbaru.

Penelitian ini sejalan dengan penelitian yang dilakukan oleh (Mursidi, 2009) dari pergurun tinggi Universitas Malang. Dimana hasil penelitian yang dilakukan menyatakan bahwa pendidikan dan pelatihan berpengaruh terhadap kinerja karyawam muhammadiyah malang.

\section{Pengaruh Motivasi dan Pendidikan dan} Pelatiah (Diklat) Secara Simultan Terhadap Kinerja Karyawan Pada PT. Hasrat Tata Jaya Pekanbaru.

Untuk melihat dan mengetahui besar pengaruh secara bersamaan (sumultan) maka dapat dilihat pada tabel 3 dibawah ini :

\begin{tabular}{|c|c|c|c|c|c|}
\hline \multirow[b]{2}{*}{ Model } & \multicolumn{4}{|c|}{$\begin{array}{c}\text { Tabel } 3 \text { Uji Anova } \\
\text { ANOVA }^{\mathrm{a}}\end{array}$} & \multirow[b]{2}{*}{ Sig. } \\
\hline & $\begin{array}{l}\text { Sum of } \\
\text { Squares }\end{array}$ & $\mathrm{df}$ & $\begin{array}{l}\text { Mean } \\
\text { Square }\end{array}$ & $\mathrm{F}$ & \\
\hline $\begin{array}{ll}1 & \begin{array}{l}\text { Regres } \\
\text { sion }\end{array}\end{array}$ & 1657,468 & 2 & 828,734 & 86,600 &, $000^{6}$ \\
\hline $\begin{array}{l}\text { Residu } \\
\text { al }\end{array}$ & 660,310 & 69 & 9,570 & & \\
\hline Total & 2317,778 & 71 & & & \\
\hline $\begin{array}{l}\text { a. Depende } \\
\text { b. Predictol }\end{array}$ & $\begin{array}{l}\text { Variable: K } \\
\text { (Constant), }\end{array}$ & endic & kan dan & atihan, I & tivasi \\
\hline $\begin{array}{l}\text { Sumber } \\
2018\end{array}$ & Hasil P & eli & an de & $n S$ & 25 \\
\hline
\end{tabular}

Eko dan Bisnis (Riau Economics and Business Reviewe) Volume 10, Nomor 3, 27 September 2019
Berdasarkan hasil uji $\mathrm{F}$ yang telah dilakukan dapat dilihat pada tabel diatas, diperoleh $\mathrm{f}$ hitung lebih besar dari f tabel yakni sebesar 86,600 > 3,13 dengan tingkat signifikansi 0,000 lebih kecil dari 0,05, ini bermakna bahwa $\mathrm{H}_{3}$ diterima. Yang berarti bahwa secara bsimultan variabel motivasi dan pendidkan dan pelatihan (diklat) berpengaruh positif dan signifikan terhadap variabel kinerja karyawan. Sehingga dapat disimpulkan bahwa motivasi dan pendidikan dan pelatihan (diklat) secara bersama-sama (simultan) berpengaruh positif dan signifikan terhadap kinerja karyawan swasta pada PT. Hasrat Tata Jaya Pekanbaru.

Penelitian ini sejalan dengan penelitian yang telah dilakukan oleh (Saprianto, 2017) dari Universitas Riau, dimana hasil penelitian yang dilakukan menunjukkan adanya pengaruh positif antara motivasi dan pendidikan dan pelatihan(diklat) terhadap kinerja pegawai pada badan kepegawaian, pendidikan dan pelatihan daerah provinsi riau.

Untuk mengetahui besar pengaruh variabel independen terhadap variabel dependent maka dilakukan uji koefisien determinasi $\left(\mathrm{R}^{2}\right)$. Berikut hasil uji koefisien determinasi dapat dilihat pada tabel dibawah ini :

\section{Tabel 4 Model Summary}

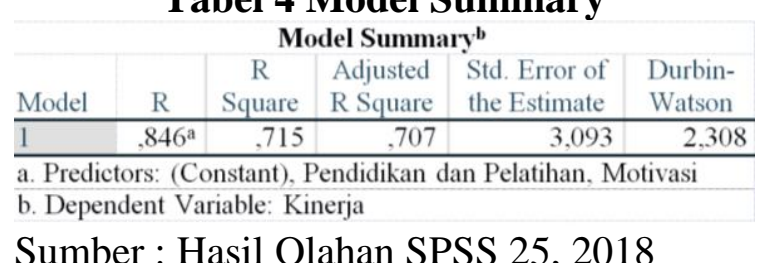

Berdasarkan hasil penelitian pada tabel diatas, dapat dilihat bahwa nilai koefisien determinasi yang diperoleh sebesar 0,715 atau sebesar 71,5\%. Hal ini menunjukkan bahwa motivasi dan diklat dapat dijelaskan sebesar 71,5\% sedangkan sisanya $28,50 \%$ dijelaskan oleh variabel lain yang tidak diteliti pada penelitian ini. Dari total $71,5 \%$ variabel motivasi merupakan variabel dominan dengan besar pengaruh sebesar 40,16\%, sedangkan variabel diklat sebesar $31,3 \%$. 


\section{SIMPULAN}

Dari hasil uji kuantitatif malalui uji regresi yang telah dilakukan, pada Uji t dapat dijelaskan bahwa secara parsial motivasi dan diklat berpengaruh positif dan signifikan terhadap kinerja karyawan pada PT. Hasrat Tata Jaya Pekanbaru. Sedangkan pada uji F dapat dijelaskan bahwa motivasi dan diklat secara simultan berpengaruh positif dan signifikan terhadap kinerja karyawan pada PT. Hasrat Tata Jaya Pekanbaru sebesar $71,5 \%$. Dari kedua variebel independent yang diteliti, variabel motivasi merupakan variabel yang paling dominan yakni dengan sumbangsih pengaruh $40,16 \%$.

Berdasarkan hasil yang telah diperoleh, maka dengan ini peneliti memberikan beberapa rekomendasi berdasarkan hasil penelitian yang telah dilakukan diantaranya:

1. untuk meningktkan pemahaman karyawan terhadap pelatihan yang dilakukan, diharapkan kepada pihak perusahaan agar kedepan dapat merubah metode pendidikan dan pelatihan yang selama ini diterapkan sehingga diharapkan dapat memaksimalkan output yang diharapakan,

2. untuk dapat meningkatkan motivasi karyawan dimasa akan datang, motivasi tidak selalu diberikan dalam bentuk finansial, melaikan dalam hal lain yang bersifat nonfinansial. Untuk itu diharapkan kepada pihak perusahaan diharapkan dapat meningkatkan motivasi karyawan melalui pemberian pujian kepada karyawan yang telah bekerja menjalankan tugas dengan baik dan memuaskan perusahaan.

3. Untuk mencapai tujuan yang telah ditetapkan, diharapkan kepada karyawan agar dapat meningkatak rasa tanggung jawab terhadap beban kerja yang telah diberikan oleh perusahaan.

Dihaharapkan bagi penelitian berikutnya agar dapat mengkaji variabel-variabel lain yang tidak di teliti pada penelitian ini.

\section{DAFTAR RUJUKAN}

AA. Anwar Prabu. (2006). Manajemen Sumber Daya Manusia Perusahaan, Penerbit PT. Remaja Rosdakarya. Bandung.

Andespa. (2011). Metodologi Riset Bisnis. Pekanbaru: Alhuda Press

Anwar, Sanusi. (2011). Metode Penelitian Bisnis. Salemba Empat. Jakarta.

As'ad, M. (2004). Psikologi Industri. Yogyakarta: Liberty

Boedijoewono, Noegroho. (2007). Pengantar Statistika Ekonomi dan Bisnis Edisi Kelima. Yogyakarta: UPP STIM YKPN.

Bungin, M. Burhan.(2008).Penelitian Kualitatif; Komunikasi, Ekonomi, Kebijakan Public Dan Ilmu Social Lainnya. Jakarta: Kencana.

Daft, Richard L. (2010). New Era Of Management. Canada: SouthWestern, Cengage Learning.

Ghozali, Imam. (2005). Aplikasi Analisis Multivariate Dengan Program SPSS, Badan Penerbit Universitas Diponegoro, Semarang.

Gomes, Faustino Cardoso. (2003). Manajemen Sumber Daya Manusia, Penerbit Andi, Yogyakarta.

Handoko, T.H. (2003). Manajemen Personalia dan Sumber Daya Manusia. Jakarta .PT. Gramedia.

Hasibuan, Malayu, (2008). Manajemen Dasar, Pengertian, Dan Masalah, Penerbit Bumi Aksara, Jakarta.

I Ketut Dartha. (2010). Pengaruh Pendidikan Dan Pelatihan (Diklat)Terhadap Kinerja Pegawai Negeri Sipil PadaSekretariat Daerah Kota Malang. Volume VI (2). Malang: Sekolah Tinggi Ilmu Ekonomi Jaya Negara.

Kadarisman, M. (2012). Manajemen Pengembangan Sumber Daya 
Manusia, Edisi Pertama, Cetakan Pertama, Rajawali Press, Jakarta.

Kartini. (2002). Manajemen Motivasi, Penerbit PT. Gramedia Widia Sarana Indonesia, Jakarta.

Kasmir. (2016). Manajemen Sumber Daya Manusia (Teori dan Praktik). Jakarta: PT. Grafindo Persada.

Malayu S.P. Hasibuan, H. (2014). Manajemen Sumber Daya Manusia. Jakarta : PT Bumi Aksara.

Mangkunegara, Anwar Prabu, 2007, Evaluasi Kinerja SDM, cetakan ke 3, Penerbit PT. Refika Aditama, Bandung.

(2009). Manajemen Sumber

Daya Manusia Perusahaan, Remaja Rusda Karya, Bandung.

Mangkunegara, A. A. A. P. (2015). Manajemen Sumber Daya Manusia Perusahaan. Remaja Rosdakarya. https://doi.org/10.1038/cddis.2011.1

Manullang. (2012). Dasar-Dasar Manajemen. Yogyakarta: Gajah Mada University Press.

Mathis, Robert. L dan Jackson, Jhon H. (2006). Manajemen Sumber Daya Manusia, Penerjemah Jimmi Sadeli dan Bayu Prawira Hie, Penerbit Salemba Empat, Jakarta.

Muhammad Ali Aqsa. (2018). Analisis Hubungan Kompensasi dengan Kinerja Karyawan PT. Bima Sakti Pertiwi Pekanbaru. Daya Saing, 4(2), 221-226. Retrieved from http://bit.ly/2LDsrV8

Mursidi. (2009). Pengaruh Pendidikan dan Pelatihan Terhadap Kinerja Karyawan. Teknik Industri, 10(2), 120-127.

Nitisemindo. (2001). Manajemen Personalia. Jakarta: Ghalia Indonesia.

Notoadmodjo, S, (2005). Metodologi Penelitian Kesehatan (Edisi Revisi). PT. Rineka Cipta, Jakarta.
Notoadmodjo, Soekidjo. (2009). Pengembangan Sumber Daya Manusia Cetakan Ke-4. Jakarta: Rineka Cipta.

P. Sondang, Siagian. (2002). Kepemimpinan Organisasi Dan Perilaku Administrasi. Jakarta: Gunung Agung.

Priansa, Juni, Donni. (2016). Perencanaan dan Pengembangan SDM . Bandung: Alfabeta.

Priyono. (2010). Manajemen Sumber Daya Manusia Cetakan Kedua. Surabaya: Penerbit Zifatama Publisher.

Rahsel, Y. (2016). Administrasi Pusat Universitas Padjadjaran Bandung ( Studi Pada Bagian Administrasi Umum UNPAD ), 02(01), 105-117.

Rivai, Veithzal, (2008), Manajemen Sumber Daya Manusia Untuk Perusahaan Dari Teori Ke Praktek, Edisi Pertama, Cetakan Ketiga, Penerbit PT. Raja Grafindo Persada, Jakarta.

Robbins, Stephen P. (2003). Perilaku Organisasi. Index. Jakarta.

Samsudin. (2006). Manajemen Sumber Daya Manusia. Cetakan ke-1 Bandung : Pustaka Setia.

Saprianto. (2017). Pengaruh lingkungan kerja dan motivasi kerja terhadap kinerja pegawai pada badan pendidikan dan pelatihan keuangan. Jurnal Manajemen Pendidikan, 5(3), $1-15$.

Sedarmayanti. (2011). Manajemen Sumber Daya Manusia (Reformasi Birokrasi Dan Manajemen Pegawai Negeri Sipil. Cetakan Kelima. Bandung: Penerbit Refika Aditama

Simamora. (2006). Manajemen Sumber Daya Manusia, Edisi Pertama, Cetakan Keempatbelas, Penerbit Bumi Aksara Jakarta. 
SufrendanYonathan Natanoel. (2013). Mahir Menggunakan SPSS secara Otodidak. Jakarta: PT. ElekMedi

Sugiyono. (2015). Metode penelitian Kuantitatif, kualitatif dan R\&D Cetakan ke-20. Bandung: Penerbit Alfabeta Komputindo.

Mangkunegara. (2005). Evaluasi Kinerja, Penerbit PT.Refika Aditama, Bandung.

Sutopo, HB. (2006). Metode Penelitian Kualitatif. Surakarta: UNS Press.

Sutrisno, Edy, (2010). Manajemen Sumber Daya Manusia, Edisi Pertama, Cetakan Pertama, Penerbit Kencana, Jakarta.

(2009). Manajemen Sumber Daya Manusia, Edisi Pertama, Cetakan Pertama. Jakarta: Kencana Prenada Media Group.

Teguh, Sulistiyani Ambar Dan Rosidah. (2009). Manajemen Sumber Daya Manusia, Konsep Teori Dan Pengembangan Dalam Konteks Organisasi Publik, Edisi Kedua, Cetakan Pertama. Jakarta: Graha Ilmu.

Umar, Husein, (2008), Metodologi Penelitian Untuk Skripsi Dan Tesis Bisnis, Edisi Kedua, Cetakan Keempat, Penerbit PT. Raja Grafindo Persada, Jakarta.

Wibowo. (2016). Manajemen Kinerja.Jakarta : PT Rajagrafindo Persada.Usmara, 2002

Widodo, Joko. (2001). Membangun Birokrasi Berbasis Kinerja. Jawa Timur : Anggota IKAPI Malang.

Wijaya, Toni. (2009). Analisis Data Penelitian Menggunakan SPSS. Yogyakarta: Universitas ATMA Jaya Yogyakarta. 